\title{
„Bóg kiełbasy i pierogów” - polskie wątki w prozie Louise Erdrich
}

\section{"God of Sausage and Pierogis." Polish Themes in the Prose of Louise Erdrich}

Abstract: This article analyses selected stereotypes present in the novels of Louise Erdrich - in the so-called Love Medicine series, The Round House, and LaRose. The author juxtaposes the deconstruction of stereotypes of Native Americans with the deepening of the psychological portraits of Polish Americans, focusing on the topics of history and religion. The most important motifs are the heroes' dependence on fundamentally understood Catholicism and on Ojibwe shamanism. The article draws attention to the effects of forced Christianization for the Ojibwe people and to the unreflective continuation of Catholicism in the descendants of Polish immigrants, both of which lead to a blurring of identity and to internal conflicts oftentimes externalized through self-destructive actions. The author also draws attention to humorous themes that show how the characters deal with the dilemmas resulting from the conflict of cultures.

Keywords: contemporary American literature, First Nations literature, Americans of Polish descent, Catholicism, shamanism

Streszczenie: Artykuł dotyczy analizy wybranych stereotypów w powieściach Louise Erdrich w tak zwanej sadze o Pillagerach oraz w The Round House i LaRose. Autorka zestawia dekonstrukcję stereotypów rdzennych Amerykanów z pogłębieniem portretów psychologicznych Amerykanów polskiego pochodzenia, koncentrując się na temacie historii i religii. Najważniejsze wątki to zależność bohaterów od fundamentalistycznie pojmowanego katolicyzmu i szamanizmu Odżibwejów. Artykuł zwraca uwagę na skutki przymusowej chrystianizacji u Odżibwejów i bezrefleksyjnie kontynuowanego katolicyzmu u potomków polskich imigrantów, co prowadzi do rozmycia tożsamości i wewnętrznych konfliktów często uzewnętrznianych przez działania autodestrukcyjne. Autorka zwraca też uwagę na wątki humorystyczne, które pokazują, jak bohaterowie stawiają czoła dylematom wynikającym z konfliktu kultur.

Słowa kluczowe: współczesna literatura amerykańska, literatura rdzennych Amerykanów, Amerykanie pochodzenia polskiego, katolicyzm, szamanizm 
Louise Erdrich poświęca w swojej prozie sporo uwagi postaciom, które mają polskie korzenie. Rzadko bywają bohaterami/bohaterkami pierwszoplanowymi i często ich portrety zawierają elementy parodystyczne czy nawet karykaturalne z elementami czarnego humoru. Podczas lektury jej powieści niektórzy czytelnicy mogą zastanawiać się nawet, czy Louise Erdrich nie lubi Polaków i jak potraktować jej nieustanne powroty do polskich wątków. Wiadomo, że Erdrich przede wszystkim zależy na skonstruowaniu wiarygodnej perspektywy Odżibwejów wzorowanych na rodzinnym rezerwacie jej matki (Turtle Mountain z Dakoty Północnej); ważne miejsce zajmuje także w jej prozie kultura amerykańska, bo jej indiańscy bohaterowie są w różnym stopniu zasymilowani $\mathrm{z}$ tą kulturą i nieistotne wydają się wątki niemieckie ze względu na pochodzenie ojca. A Polacy? Wiadomo, że babka pisarki ze strony ojca (niespokrewniona z nią, bo była drugą żoną dziadka) Mary Korll miała polskie pochodzenie i zainspirowała Erdrich do stworzenia jednej z charyzmatycznych bohaterek powieści Klub śpiewających rzeźników ${ }^{1}$. Tej babce Erdrich dedykowała też tomik poetycki Jakclight, więc skojarzenia z tą postacią są zdecydowanie pozytywne. Jednak na kartach powieści Erdrich pojawiają się bohaterowie o polskich korzeniach, którym daleko do ideału: czarny charakter Pauline Puyat (późniejsza siostra Leopolda), fanatyczka religijna i morderczyni, Roy Waltzka, alkoholik i sprawca śmierci rodziny z małym dzieckiem, oraz Travis Wozniak, weteran wojenny i ksiądz łamiący celibat. O ile niewiele można powiedzieć w obronie Waltzki poza tym, że był ofiarą nałogu i pomimo swoich wad wykazywał empatię dla rdzennych Amerykanów, w przypadku Puyat i Wozniaka mamy wspólny wyróżnik - kultura polska w ich wydaniu to przede wszystkim uwikłanie w katolicyzm i kwestie chrystianizacji Odżibwejów. Wielu badaczy Erdrich zgadza się, że etnohistoryczna rekonstrukcja losów rdzennych Amerykanów jest jednym z najważniejszych celów jej twórczości. Trudno się nie zgodzić, że historia chrystianizacji stanowi ważny wątek tej historii, dlatego wydaje mi się, że warto prześledzić polskie ślady w tej rekonstrukcji i odpowiedzieć przy okazji na pytanie, do jakiego stopnia udało się Erdrich wyjść poza stereotyp Polaka katolika i czemu służy antyklerykalizm w jej powieściach.

Zanim przejdę do bardziej szczegółowej analizy reprezentantów kleru w wybranych powieściach Erdrich, chciałabym przypomnieć kilka faktów historycznych na temat Odżibwejów. Jak ustaliły w swoich badaniach Connie A. Jacobs $^{2}$ i Julie Moristuen-Rodakowski ${ }^{3}$, Odżibwejowie już od XVII wieku współpracowali z francuskimi traperami, wchodząc w trwałe relacje handlowe i rodzinne. Wówczas Dakota Północna (miejsce akcji powieści Erdrich, które

${ }^{1}$ L. Erdrich, Klub śpiewających rzeźników, tłum. K. Bieńkowska, Warszawa 2003.

C.A. Jacobs, The Novels of Louise Erdrich. Stories of Her People, New York 2001.

${ }^{3}$ J. Moristuen-Rodakowski, The Turtle Mountain Reservation in North Dakota in Louise Erdrich's Love Medicine [w:] Louise Erdrich's „Love Medicine”. A Casebook, red. H.D. Sweet Wong, Oxford 2000. 
chciałabym opisać) kolonizowana była przez Francuzów. Z relacji z Francuzami Odżibwejom pozostał język francuski obecny w dialekcie Mitchif oraz właśnie katolicyzm. Reprezentanci Kościoła rzymskokatolickiego pojawili się wśród Odżibwejów już w roku 1817 i pomimo początkowych niepowodzeń ich misja ostatecznie się udała, bo zdołali nawrócić większość swoich nowych parafian, chociaż zazwyczaj rozwijał się wśród nich synkretyzm religijny i katolicyzm funkcjonował obok animistycznych wierzeń ludności rdzennej. Najważniejszym punktem odniesienia w rodzinie był dla Erdrich jej dziadek ze strony matki, wódz Odżibwejów i wyznawca synkretycznej wersji katolicyzmu Patrick Gourneau z rezerwatu Turtle Mountain. Sama pisarka jako dziecko nauczycieli z Biura do Spraw Indian wychowywała się w miejscowości w pobliżu rezerwatu, więc jej wizyty u ukochanego dziadka były częste i wiadomo, że to on jest pierwowzorem postaci tradycjonalisty Nanapusha oraz ojca Damiana Modeste'a z sagi o Pillagerach ${ }^{4}$. Co ważne, Erdrich odebrała katolickie wykształcenie i, jak tłumaczy w jednym z wywiadów ${ }^{5}$, doświadczyła ze strony zakonnic zarówno wsparcia, jak i szokującej surowości. Pisarka żartuje nawet, że literatura stała się przestrzenią, w której mogła się z nimi zmierzyć, a nawet w pewnym sensie się zemścić.

Przyjrzyjmy się zatem, jak konstruuje reprezentantów kleru katolickiego na przykładzie trzech postaci: Pauline Puyat/siostry Leopoldy, Agnes DeWitt/ ojca Damiena Modeste'a z sagi o Pillagerach oraz ojca Travisa Wozniaka z powieści The Round House ${ }^{6}$ i LaRose ${ }^{7}$. Pauline Puyat poznajemy jako Metyskę żyjącą w fikcyjnym rezerwacie (wzorowany na Turtle Mountain w powieściach Erdrich pozostaje bezimienny) w drugiej dekadzie XX wieku. Wiadomo, że pochodzi z biednej (w późniejszych powieściach okazuje się, że także patologicznej) rodziny i jest traktowana z pogardą zarówno przez Odżibwejów, jak i katolickie zakonnice, które wolą przyjmować białe dziewczyny do klasztoru. W powieści Tracks możemy prześledzić drogę Pauline od nieciekawej, lekceważonej dziewczyny do nowicjuszki, która swoim zapałem religijnym prześciga wszystkich. Jak już wspomniałam, jest zdecydowanie czarnym charakterem. Odżibwejowie masowo umierają w trakcie kolejnych epidemii, a Pauline staje się „łowcą dusz” dla Chrystusa, którego niezmiennie wyobraża sobie jako białego mężczyznę. Erdrich konstruuje Pauline w sposób karykaturalny, wydobywając jej skłonności sadomasochistyczne objawiające się nieustannym umartwianiem własnego ciała i kompletnym wyparciem własnej kultury. Ambicje Pauline są tak wielkie, że nie powstrzymują jej nawet przed oddaniem własnego dziecka (którego nie udało jej się zabić) i zamordowaniem kochanka. Jej

${ }^{4}$ Saga obejmuje: Love Medicine, Tracks, The Bingo Palace, The Last Report on the Miracle at Little No Horse, Tales of Burning Love, Four Souls.

5 „The Art of Fiction” zima 2010, nr 208 (195).

${ }^{6}$ L. Erdrich, The Round House, New York 2012.

7 Taż, LaRose, New York 2016. 
fanatyzm jest podsycany przez rywalizację z Fleur Pillager, odżibwejską szamanką, i stopniowo obserwujemy jej postępujące szaleństwo. Erdrich wraca do Pauline w innych powieściach cyklu, najwięcej miejsca poświęca jej w Love Medicine ${ }^{8}$ The Last Report on the Miracle at Little No Horse', w której Pauline jest już siostrą Leopoldą, znęcającą się nad swoją córką Marie podczas jej wizyty w klasztorze, oraz słynną z jeszcze większego samoumartwiania i demonicznej charyzmy. W ostatniej z wymienionych powieści Kościół katolicki pod przywództwem Jana Pawła II rozważa beatyfikację Leopoldy i na świadka powołuje ojca Damiena z rezerwatu Pillagerów, drugą postać wartą omówienia. Zanim do tego przejdę, chciałabym tylko wspomnieć, że w portrecie Pauline można dostrzec pokrewieństwo ze słynną postacią historyczną, irokeską świętą Kateriną Tekakwithy, która również całkowicie wyparła się własnej kultury i słynęła z samoumartwiania. Irokezi podobnie do Odżibwejów byli chrystianizowani przez francuskich księży. Świętość Tekakwithy do dzisiaj może budzić kontrowersje, zwłaszcza w kontekście przymusowej chrystianizacji można odnieść wrażenie, że była ona głównie ofiarą kolonizacji i jej przedwczesna śmierć na pewno miała związek z samoumartwianiem, do którego ją zmuszano, i brutalnym oderwaniem od własnej kultury. Co istotne, w powieści The Last Report... Erdrich również skłania się do interpretacji losów Pauline/Leopoldy jako losów ofiary kolonizacji. Pisarka odsłania przed czytelnikiem nieznane fakty z życia zakonnicy, podając, że była dzieckiem polskiego arystokraty o mrocznej przeszłości i Odżibwejki, która została odrzucona przez swój klan za zamordowanie własnej matki. W tym kontekście była jednym z dzieci ze złego związku, które nie miało szansy na funkcjonowanie w żadnej z kultur i ta pozycja napiętnowanego wyrzutka była pierwszym krokiem na drodze do demoralizacji.

Drugim ważnym misjonarzem w powieściach Erdrich jest ojciec Damien Modeste, który stanowi kontrast dla Pauline/Leopoldy. Nie tylko rozumie Odżibwejów, ale także promuje rodzaj chrześcijańskiego pacyfizmu w powieści Tracks ${ }^{10}$. Postać Damiena zostaje znacznie rozbudowana w powieści The Last Report..., w której przez retrospekcję poznajemy życie tego bohatera od jego urodzin do śmierci, obejmujące prawie cały XX wiek. Zaskoczeniem dla czytelnika może być fakt, że tak jak Pauline Damien jest zakładnikiem własnych kłamstw. Największą mistyfikacją jest podawanie się za mężczyznę i katolickiego księdza, ponieważ Damien tak naprawdę jest kobietą. Naprawdę nazywał się Agnes DeWitt i w przeszłości był zakonnicą, siostrą Cecilią. Oprócz miłości do życia duchowego siostra Cecilia kochała także muzykę Fryderyka Chopina, która wprawiała ją w stan ekstazy, i jeden z takich koncertów fortepianowych kosztował ją wyrzucenie z zakonu. Przez jakiś czas potem Agnes

\footnotetext{
8 Taż, Love Medicine, New York 1984.

9 Taż, The Last Report on the Miracle at Little No Horse, New York 2001.

10 Taż, Tracks, New York 1988.
} 
pozostawała w związku uczuciowym z farmerem, ale ten związek zakończył się jego niespodziewaną śmiercią. Agnes trafiła następnie do rezerwatu Odżibwejów w przebraniu księdza ( $w$ trakcie powodzi straciła własne ubranie i tymczasowo założyła znalezioną sutannę) i bardzo dobrze odnalazła się w pracy misjonarza. Stała się dokładnym przeciwieństwem sadystycznej siostry Leopoldy. Jedyny problem stanowiły wyrzuty sumienia z powodu kłamstwa, które nasiliły się pod koniec życia. W tym czasie do rezerwatu przybyli reprezentanci komisji beatyfikacyjnej z Watykanu mający ustalić świętość Leopoldy i to ojciec Damien miał podjać decyzję, czy wyznać prawdę na temat Leopoldy i odsłonić własną tożsamość, przy okazji rujnując życie tych Odżibwejów, którym udzielił sakramentów.

Trzecim misjonarzem skonstruowanym przez Erdrich jest ojciec Travis, który podobnie do poprzedników pojawia się w jednej powieści (The Round House) i powraca w kolejnej (LaRose) jako postać bardziej wieloznaczna. Tak jak Leopolda i Damien Travis cierpi na rozszczepienie osobowości; jego życie pełne jest sekretów, a on sam nie stanowi dobrego przykładu dla parafian. Pochodzi z rodziny polskich imigrantów (to oni zostawiają mu wykorzystane przeze mnie w tytule dziedzictwo „Boga kiełbasy i pierogów”) i cierpi na syndrom stresu pourazowego po ataku na ambasadę amerykańską w Libanie. Dowiadujemy się także, że jest fanem science fiction i nie udaje mu się zachować celibatu (wdaje się w romans z Odżibwejką, wierną parafianką zreszta).

Powyższe przykłady dostarczają dowodów na to, że Erdrich, dystansując się od katolicyzmu, prezentuje wyznawców tej religii w sposób często naznaczony ironią i czarnym humorem. Warto przy tym zaznaczyć, że krytyka katolicyzmu nie służy uwypukleniu zalet duchowości szamańskiej Odżibwejów. Wielu badaczy Erdrich (na przykład Catherine Rainwater) ${ }^{11}$ zauważa, że pisarka najczęściej sytuuje swoich bohaterów na marginesie, w tym wypadku pozostają na marginesie katolicyzmu i szamanizmu, z dala od ortodoksji. Są to bohaterowie portretowani w nieustannym ruchu, często poszukujący tożsamości i kwestionujący zastane systemy wartości. Nic w tym dziwnego, skoro zderzenie modelu euro-amerykańskiego z modelem ludności rdzennej Ameryki musiało zaowocować chaosem na wielu poziomach. Wszyscy bohaterowie Erdrich targani są sprzecznościami, nie tylko reprezentanci kleru katolickiego. Jednocześnie cały czas w centrum zainteresowania pisarki pozostaje historia Odzzibwejów i szerzej rdzennych Amerykanów, historia, która we współczesnych Stanach Zjednoczonych wciąż jest zbyt słabo znana i rozumiana, również dlatego, że trudno ją znaleźć w szkolnych podręcznikach. Warto w tym miejscu zauważyć, że uniwersalizm prozy Erdrich zasadza się również na fakcie, że nie tylko w Ameryce istnieje problem historii przemilczanych i/lub wypartych. W Polsce w podobny sposób „omijamy” historię Żydów w podstawie programowej

${ }^{11}$ C. Rainwater, Reading Between Worlds: Narrativity in the Fiction of Louise Erdrich [w:] Louise Erdrich's „Love Medicine”..., dz. cyt. 
dla szkół i ponosimy tego konsekwencje. W obu przypadkach przemilczane/ niedopowiedziane historie pozostają w cieniu ludobójstwa, w Polsce oczywiście głównymi sprawcami byli niemieccy naziści, ale polski antysemityzm nie był bez znaczenia. Również w Stanach Zjednoczonych eksterminacja rdzennej ludności odbywała się z inicjatywy części społeczeństwa, ale wszechobecny rasizm miał poparcie ogromnej większości i trudno nie zauważyć, że nadal istnieje przyzwolenie na ksenofobię; w końcu marzenie o wielokulturowej, wolnej od konfliktów Ameryce nigdy się nie ziściło.

Wartość prozy Erdrich polega również na tym, że udaje jej się za pomocą środków literackich wykreować świat, który zmusza nas do intelektualnego i emocjonalnego uczestnictwa w wydarzeniach odsłaniających przyczyny konfliktów etnicznych trawiących współczesną Amerykę. Erdrich nie tylko pokazuje, na czym polegała polityka eksterminacji realizowanej głównie przez oszukańcze traktaty i czasami zakażone koce, ale także ilustruje zagładę kultury, koncentrując się na konsekwencjach ustawy Dawesa, która pod pretekstem uczynienia z rdzennych Amerykanów farmerów pozbawiła ich dwóch trzecich ziemi i ułatwiła zamknięcie w rezerwatach. Erdrich skupia się też na skutkach przymusowego odbierania dzieci rdzennym Amerykanom (w niektórych stanach pod groźbą więzienia) i umieszczania ich w szkołach z internatem (protestanckich i katolickich); bite, głodzone i odzierane z języka i kultury często płaciły za to życiem. Ci, którzy powrócili, wracali z traumą. Alkoholizm i prostytucja to również konsekwencje kolonizacji, która dla rdzennych Amerykanów trwa nadal. W końcu konstytucja USA, która przypieczętowała wyzwolenie od brytyjskiego kolonizatora, od początku wykluczała rdzennych Amerykanów jako dzikich. To szokujące, że ta grupa etniczna uzyskała prawa obywatelskie jako ostatnia w 1924 roku (w niektórych stanach jeszcze później), prawo do wolności wyznania w 1978 roku, prawo do ochrony miejsc pochówku dopiero w 1990. To zaledwie kilka faktów z długiej historii, które zmieniają zupełnie obraz ludzi, przez wiele dekad podlegających stereotypizacji pochodzącej z fabryki snów Hollywood. Westerny to oczywiście nie tylko przemysł filmowy, ale także książki, tradycja, która rozwinęła się i w USA, i w Niemczech (nawet Adolf Hitler miał słabość do „indiańskich” opowieści Karola Maya) czy Polsce ${ }^{12}$.

Louise Erdrich zawsze dekonstruuje stereotypy, nie godząc się na upraszczające i często infantylne przedstawienia rdzennych Amerykanów jako Szlachetnych Dzikusów, Krwiożerczych Wojowników czy Znikających Indian ${ }^{13}$. Czy jednak udaje jej się uniknąć stereotypizacji innych grup? Czy potrafi wyjść,

12 Pisali o tym między innymi: M. Bordewich, Killing the White Man's Indian, New York 1996; V. Deloria Jr., Custer Died For Your Sins. An Indian Manifesto, New York 1969 czy szerzej na temat historii J. Wilson, The Earth Shall Weep: A History of Native America, New York 1998 oraz Th. King, The Inconvenient Indian. A Curious Account of Native Fergus People in North America, Minneapolis 2012.

13 Reel Injun, reż. N. Diamond, 2009 (dokument). 
na przykład, poza stereotyp fanatycznego katolika oddającego cześć wyłącznie „Bogu kiełbasy i pierogów”? Żeby odpowiedzieć na to pytanie, należy przyjrzeć się najpierw jej ulubionym strategiom literackim, które pomagają naświetlić kwestie wielokulturowości.

Erdrich jest powieściopisarką, która stara się zaprezentować światopogląd Odżibwejów, uwzględniając nie tylko przeszłość, ale także współczesność, i dlatego interesują ją głównie tożsamość metyska i dziedzictwo transkulturacji. Wielu badaczy zwraca uwagę (Rainwater ${ }^{14}$, Louis Owens ${ }^{15}$, Michelle Kloppenburg ${ }^{16}$ ), że udało jej się na nowo zinterpretować figurę trickstera, stworzyć cykle opowiadań oparte na dwóch koncepcjach czasu: linearnej (z kultury Zachodu) i cyklicznej (tradycja ludności rdzennej) i wprowadzić narratorów, którzy pełnią funkcję mediatorów międzykulturowych. Erdrich zazwyczaj opisuje zderzenie świata Odżibwejów i Amerykanów, które doprowadziło do kulturowej katastrofy tych pierwszych. Pomimo podkreślania kontrastów Erdrich wypracowała strategię, która nadaje spójność jej fikcyjnemu światu i jest to sposób konstruowania bohaterów. Rainwater zauważa, że odżibwejscy bohaterowie Erdrich zazwyczaj zakorzenieni zostają w mitologii tej grupy kulturowej (na przykład ich charakterystyka jest wzmocniona przez odniesienie do zwierząt totemicznych i ich cech), ale też są to postacie wiarygodne psychologicznie w konwencji realistycznej ${ }^{17}$. Elementy mitologiczne zazwyczaj wprowadzane są przez techniki typowe dla realizmu magicznego, od którego pisarka się odżegnuje, ale nigdy nie wypiera się pokrewieństwa literackiego z Gabrielem Garcíą Márquezem ${ }^{18}$.

Moim zdaniem Erdrich stosuje podobną strategię łączenia mitologii z realizmem psychologicznym w przypadku konstruowania bohaterów europejskich i amerykańskich. Zwłaszcza wyraźnie widać to w sposobie, w jaki tworzy reprezentantów kleru katolickiego. Pauline, Damien i Travis są zakorzenieni w mitologii judeochrześcijańskiej i jednocześnie zostali sportretowani wiarygodnie psychologicznie. Oczywiście ten temat powinien być rozwinięty, ale jest tak szeroki, że stanowi materiał na książkę, a nie artykuł; wspomnę więc tylko o głównych dowodach na taką strategię literacką. W powieści Tracks Pauline wyobraża sobie siebie jako Chrystusa (jest męczennicą za wiarę i wybranką w swojej wizji), a z kolei w The Last Report on the Miracles No Horse Damien trzy razy jest kuszony przez diabła. Zatem ta podwójna charakterystyka,

${ }^{14}$ C. Rainwater, Dreams of Fiery Stars. The Transformations of Native American Fiction, Philadelphia 1999.

15 L. Owens, Other Destinies: Understanding the American Indian Novel, Norman 1992.

${ }^{16}$ M.R. Kloppenburg, Contemporary Trickster Tales: The Pillagers in Louise Erdrich North Dakota Quartet and Their Stories of Survival, Essen 1999.

${ }^{17}$ C. Rainwater, Reading Between Worlds..., dz. cyt.

${ }^{18}$ Hans Bak proponował nazwę „tribal realism”, zob. tenże, Toward a Native American "Realism”: The Amphibious Fiction of Louise Erdrich [w:] Neo-Realism in Contemporary American Fiction, red. K. Versluys, Amsterdam 1992. 
mitologiczno-psychologiczna, stanowi wspólny mianownik i zarazem jeden z wielu międzykulturowych mostów, który Erdrich konstruuje ${ }^{19}$.

Przyglądając się charakterystyce psychologicznej reprezentantów kleru, można zauważyć schizofreniczne nieomal rozbicie osobowości. Warto od razu zaznaczyć, że takie „pęknięcie” jest też typowe dla większości Odżibwejów i Metysów w prozie Erdrich. W przypadku tych drugich Erdrich wyraźnie sugeruje, że problemy psychiczne są pokłosiem polityki imperialnej USA, w tym głównie traumy po eksterminacji przodków czy przymusowej asymilacji do kultury amerykańskiej. Są to zatem konsekwencje wydarzeń historycznych i aktów prawnych, o których wspomniałam wcześniej. Na przykład Fleur Pillager, odżibwejska szamanka, ale i skuteczna businesswoman, staje się patologiczną matką, gdy traci ziemię w konsekwencji ustawy Dawesa. Nector Kaspaw, wódz plemienia, całe życie pozostaje ofiarą szkoły z internatem, bo nie wie, kim do końca jest, a Lipsha Morrisey, wnuk Fleur i wieczny nieudacznik, pochodzi z rodziny zniszczonej przez alkohol i prostytucję. Takich przykładów w powieściach Erdrich można znaleźć o wiele więcej i łatwo zauważyć, że Erdrich nie interesuje idealizowanie bohaterów, wprost przeciwnie, chce ich pokazać jako złożonych ludzi, częściowo odpowiedzialnych za własne słabości, ale także często bezsilnych, ponieważ zostali brutalnie pozbawieni własnego uniwersum kulturowego i muszą funkcjonować pomiędzy światami, które są nie do pogodzenia w tak wielu aspektach.

Kler katolicki również doświadcza konfliktu międzykulturowego. Jak już pisałam, Pauline Pyuat jest ambitną Metyską, odrzuconą lub też niewystarczająco docenianą przez Odżibwejów, i to popycha ją do szukania dowartościowania w świecie białych zakonnic. Nie jest wystarczająco biała, żeby zostać przyjęta do klasztoru na normalnych warunkach, więc stara się udowodnić, że jest największą męczennicą i najgorliwszą wyznawczynią w tej części świata, co skutkuje przeobrażeniem się w potwora. W przeciwieństwie do niej Damien

${ }_{19} \mathrm{Na}$ temat tego, do jakiego stopnia współcześni pisarze z kręgu rdzennych Amerykanów potrafią wykorzystać swoje autentyczne dziedzictwo kulturowe, istnieje stary spór pomiędzy twórcami opowiadającymi się za otwarciem na białych czytelników i artystami/intelektualistami, którzy wierzą w separatyzm i traktują zabiegi łączące obie kultury za rodzaj zdrady lub poświęcenia kultury oryginalnej. W pierwszym obozie krytyków znajdują się między innymi Owens, Rainwater czy Arnold Krupat (zob. tenże, Ethnocriticism. Ethnography, History, Literature, Berkeley 1992; tenże, The Turn to the Native. Studies in Criticism and Culture, Lincoln 1996), a w drugim Elisabeth Cook-Lynn czy David Truer. Ten ostatni, skądinąd bardzo dobry pisarz z tego samego kręgu kulturowego co Louise Erdrich, napisał słynną polemiczną książkę, w której w ogóle kwestionuje istnienie współczesnej literatury rdzennych Amerykanów (D. Truer, Native American Fiction. A User's Manual, Minneapolis 2006). Moim zdaniem spory te odzwierciedlają problemy tożsamościowe i kwestie zaakceptowania bądź nie kultury metyskiej jako kontynuacji tradycji indygenistycznej oraz fakt, że przynależność do poszczególnych kultur indiańskich w USA jest regulowana w bardzo różny sposób (czasami wystarczą kwoty krwi, a kiedy indziej przodkowie muszą figurować w spisach ludności z lat trzydziestych XX wieku lub stosuje się jeszcze inne kryteria, które umożliwiają stanie się członkiem jednego z narodów indiańskich). 
postrzega kulturę Odżibwejów jako bardziej egalitarną niż judeochrześcijańska i nie godzi się na typowe dla Kościoła katolickiego spychanie kobiet na niższą pozycję ${ }^{20}$. Damien staje się też zrównoważonym mądrym duchownym (czego nie można powiedzieć o siostrze Leopoldzie, w którą zmieniła się Pauline), ale równowagę duchową uzyskuje przez odejście od ortodoksyjnego katolicyzmu. Pauline/Leopolda nie rozwija się, do końca pozostaje osobą przepełnioną zemstą i nadużywającą władzy, Damien natomiast ma dynamiczną osobowość i rozumie, że jeżeli tradycja kulturowa ma przetrwać, musi zostać mądrze zmodyfikowana, aby odpowiadała potrzebom współczesności bez zatracenia oryginalnego rdzenia dziedzictwa. Sztywna perspektywa dogmatyczna jest z natury wykluczająca, zwłaszcza dla Metysów, którzy często skazani są na łączenie tradycji. Kościół katolicki, któremu Damien służy, nazywa takie podejście herezją i nie jest też gotowy na przyznanie, że praca misjonarska w ogóle jest etycznie kontrowersyjna. Historycznie rzecz ujmując, większość rdzennych Amerykanów była nawracana siłą oraz groźbą, więc wybierali chrześcijaństwo pod przymusem, przytłoczeni rozpaczą niezależnie od modelu kolonizacji (hiszpańskiego, francuskiego czy angielskiego). Narzucane chrześcijaństwo było jednym z przejawów przemocy Europejczyków, z nielicznymi wyjątkami, takimi jak Fray Bernardino de Sahagún czy misje jezuickie w Paragwaju, które jednak w żaden sposób nie równoważą brutalności misjonarzy franciszkańskich kolonizujących Kalifornię czy „dokonań” Juana de Ońate, który obciął kilkuset mężczyznom Pueblo stopę i zmasakrował tysiące innych grup indiańskich w czasie swoich rządów ${ }^{21}$. Chociaż od zawsze toczą się spory, która kolonizacja (hiszpańska, francuska czy angielska) była bardziej brutalna i czy można porównywać okrucieństwo europejskiego podboju Ameryki z krwawymi podbojami Azteków, Inków czy Irokezów i Komanczów, to wydaje mi się, że niewiele wnoszą takie zestawienia. Najambitniejsi reprezentanci współczesnej literatury rdzennych Amerykanów nie koncentrują się na okrucieństwie, ale pokazują wspólne ludzkie dziedzictwo, odsłaniają indywidualne losy osadzone w weryfikowalnym kontekście historycznym, żeby nie tylko przybliżać pomijane wątki historyczne, ale także wzbudzić empatię do ofiar przemilczanej przemocy, którą tak długo zakrywano hasłami o konieczności szerzenia postępu i cywilizacji.

Jest to oczywiste, że Damien, próbując odzyskać integralność (w amerykańskiej społeczności Agnes DeWitt nie mogła pogodzić sprzeczności funkcjonowała jako szalona zakonnica lub łamiąca tabu kulturowe kochanka), musi przede wszystkim odrzucić przemoc i z tego powodu przekształca tradycyjny katolicyzm w religię synkretyczną. Zmiany dokonują się stopniowo, a ich ukoronowaniem jest zastąpienie figury Matki Boskiej figurą Pani

${ }^{20}$ Wiele kultur rdzennych Amerykanów miało tradycję matrylinearną, więc pozycja kobiet była znacznie wyższa niż w tradycji chrześcijańskiej.

${ }^{21}$ Między innymi w: T. Horwitz, Podróż dtuga i dziwna. Drugie odkrywanie Nowego Świata, Warszawa 2011. 
od Węży (Lady of Serpents), która, podobnie do Matki Boskiej z Gwadelupy, spaja tradycję indiańską i chrześcijańską. Damien nazywa siebie „następcą Nanapusha”, czyli odżibwejskiego konserwatysty noszącego imię po tricksterze, i oprócz codziennej mszy korzysta też z rytuałów szamańskich, takich jak oczyszczenie w łaźni parowej (sweat lodge). Według Damiena Odżibwejowie nie potrzebują „mirthless trained puppet of the dogma” („pozbawiona radości, wytresowana na dogmatach pacynka" ${ }^{22}$. On sam, czy raczej ona, Agnes DeWitt, również nie chce być tresowaną marionetką, ponieważ zależy jej na rozwoju duchowym i intelektualnym, a taki holistyczny rozwój nie jest możliwy przez praktykowanie religii obarczonej tyloma ograniczeniami. Co więcej, misja Agnes/Damiena staje się formą rekompensaty za traumę wynikającą z przymusowego nawrócenia. Taka interpretacja staje się możliwa po uwzględnieniu roli, jaką w tej powieści odgrywa historia Pauline/Leopoldy. Jak już wspominałam, postać ta przestaje być postrzegana w tej powieści jako wyłącznie winowajczyni i zaczyna jawić się jako również ofiara. Agnes/Damien czuje moralne zobowiązanie, żeby poświęcić się dla takich ludzi. Jak wyjaśnia: „Pauline (...) was the residue of what occurred when some of our grief-mad people trampled their children” („osobowość Pauline składała się z resztek pozostawionych przez ludzi, którzy oszaleli z rozpaczy i zadeptali własne dzieci” $)^{23}$. W końcu była dzieckiem polskiego arystokraty doświadczonego przez „secret Old World cruelties” („tajemnicze okrucieństwa Starego Świata”) ${ }^{24}$ oraz Odżibwejki matkobójczyni. Rdzenni Amerykanie są aktywnymi uczestnikami historii i również dokonują złych wyborów - ich skłonność do błędów czyni ich bardziej ludzkimi i odziera z posągowych stoickich masek, które tyle razy nakładano im w westernach. Agnes/Damien, poznając prawdę o Pauline, zyskuje też świadomość, że historia to puszka Pandory, więc niektóre sekrety są zbyt niebezpieczne, aby się nimi dzielić i trzeba nauczyć się wybaczać. The Last Report... staje się bolesną historią pojednania.

To pojednanie i integracja dokonują się nie tylko na poziomie wspólnoty czy społeczności, ale także w wymiarze indywidualnym. Ojciec Damien jest jedynym przedstawicielem kleru w powieściach Erdrich, który odnajduje równowagę i harmonię. Przekształca dogmatyczny katolicyzm w religię synkretyczną, aby zlikwidować sztywne granice opisane w Biblii: pomiędzy człowiekiem i zwierzętami, mężczyzną i kobietą, ożywionymi i nieożywionymi elementami stworzenia. Animistyczna religia Odżibwejów nie skupia się na dychotomii, ale

${ }^{22}$ L. Erdrich, The Last Report..., dz. cyt., s. 276.

${ }^{23}$ Tamże, s. 158. Erdrich odwołuje się tutaj do swojej ulubionej metafory rdzennych Amerykanów jako bizonów, przywołując obraz tych zwierząt tratujących swoje młode przed masowym odstrzałem dokonanym przez Amerykanów w drugiej połowie XIX wieku. Całkowita eksterminacja bizonów w tamtym czasie miała pozbawić pożywienia Indian z Wielkich Równin i ułatwić umieszczenie ich w rezerwatach; plan się udał.

${ }_{24}$ Tamże, s. 157. 
eksponuje łączność pomiędzy wszystkimi elementami. W ten sposób Agnes/ Damien scala również swoją rozszczepioną osobowość. Jej męska rola staje się wyborem; odżibwejscy przyjaciele nie traktują tej decyzji jako czegoś nienormalnego, chociaż nie rozumieją, dlaczego Damien musi kłamać i żyć w przebraniu. Tradycja Odzzibwejów jest pod tym względem bardziej pojemna i mniej zorientowana na doktryny i dogmaty oraz przymus nawracania innych.

Ostatnim reprezentantem kleru, o którym chciałabym wspomnieć, jest ojciec Travis. W jego przypadku również istnieje pokusa, aby diagnozować u niego schizofrenię. Jednak nietrudno zauważyć, że Erdrich nie dostarcza nam wystarczająco dużo materiału, żeby możliwa była wiarygodna diagnoza konkretnego schorzenia psychicznego. Pauline/Leopolda i Travis niewątpliwie ponosili konsekwencje traumy (Pauline ze względu na patologie rodzinne, a Travis jako weteran piechoty morskiej) i na pewno nie znaleźli ukojenia w Kościele katolickim. Myślę, że brak doprecyzowania ich kondycji psychicznej jest u Louise Erdrich celowy, w ten sposób autorka częściowo osłabia natręctwo stereotypu. Odnoszę wrażenie, że określenia „katolicki fanatyk” czy „katolicka fanatyczka” w odniesieniu do wszystkich misjonarzy chrześcijańskich są tak samo nietrafione jak fraza „szlachetny dzikus” używana w celu opisania rdzennych Amerykanów. Oczywiście możemy uznać, że w każdym stereotypie jest ziarnko prawdy i że czasami jest to wygodny „skrót” kulturowy. Ale oprócz tego stereotyp jest też poważnym uproszczeniem rzeczywistości, który świadczy o przedkładaniu naszej wygody nad rzetelność badawczą. Opowiadanie historii poprzez stereotypy jest szczególnie niebezpieczne. Poważne traktowanie historii wymaga wykorzystania wielu perspektyw i odsłonięcia lub przynajmniej sygnalizowania jej złożoności. Jest to bardzo wymagające zadanie, ale ważne zwłaszcza w świecie „fake newsów” i „postfaktów”; w świecie ludzi tak przytłoczonych ilością informacji, że część z nich nawet nie próbuje ich przetworzyć. Nadmiar powoduje odwrót w stronę łatwo przyswajalnych czarno-białych prawd, które dają iluzję poznawczego komfortu. Ale te same „prawdy” stają się pożywką dla radykalizmów i sprzyjają wymianie informacji poprzez komunały. Z perspektywy mediów społecznościowych Polska jest krajem rozdartym pomiędzy katolickich fanatyków i lewicowych radykałów, a Stany Zjednoczone są podzielone przez kolorowych entuzjastów wielokulturowości i białych zwolenników nowej, wspaniałej Ameryki („America made great again” / „Ameryki znów wspaniałej”). W obu wypadkach brakuje środka i trudno potraktować tę polaryzację jako wiarygodny obraz społeczeństwa i kultury. Katolicyzm w Polsce nie jest monolitem, tak samo jak prawicowe sympatie w USA nie dotyczą tylko białej ludności; liczba Afroamerykanów, Amerykanów o korzeniach latynoskich i kobiet głosujących na Donalda Trumpa na pewno pokazuje, że społeczeństwo amerykańskie jest podzielone na wiele sposobów.

Doceniam Erdrich za wiele osiągnięć, ale za szczególnie cenną uważam jej umiejętność komunikacji ponad podziałami. Jej proza zawsze zawiera sporo odniesień politycznych, ale zawsze bardziej interesuje ją pisanie literatury niż 
tworzenie ideologii. Od samego początku kariery zaznaczała, że tak samo ważne są niemieckie korzenie jej ojca jak odżibwejskie i francuskie korzenie matki i od zawsze interesowała ją wielowątkowa, wielopoziomowa historia Ameryki. Jej powieści nieustannie przypominają o tym, ile jeszcze musimy zrobić, aby zrozumieć, co ukształtowało naszą pamięć. W Polsce podobny projekt udało się zrealizować Oldze Tokarczuk w Księgach Jakubowych, które, notabene, również opowiadają o mniejszości i ich głównym bohaterem również jest heretyk, z jednej strony ceniący rozwój duchowy jak ojciec Damien, a z drugiej zakochany we władzy i autodestrukcyjny jak siostra Leopolda. Ten niedokończony projekt literacki w służbie historii wielogłosowej najlepiej podsumowuje cytat z powieści The Last Report...: „each name you hear on this reservation is an unfinished history. A destiny that opens like a cone pouring out a person's life” (,każde imię zasłyszane w tym rezerwacie stanowi niedokończoną historię. Przeznaczenie otwarte jak szyszka, z której wysypują się resztki czyjegoś życia” $)^{25}$.

Konkludując, reprezentanci kleru katolickiego w powieściach Erdrich są skonstruowani w podobny sposób jak jej bohaterowie z kultury Odżibwe. Chociaż zazwyczaj na początku ich portrety wydają się bardziej karykaturalne, stopniowo rozwijają się i stają się złożonymi postaciami, przy opisie których autorka posiłkuje się wiedzą psychologiczną i odniesieniami mitologicznymi. Różne są ich losy: Leopolda umiera jako morderczyni i fałszywa święta, Damien zabiera swój sekret do grobu, a Travis zostaje przeniesiony do innej parafii, ale nie potrafi się zdecydować, czy będzie nadal ksiądzem. Erdrich udaje się pokazać, że nie wolno sądzić po pozorach i że ocenianie danej kultury tylko z jednej perspektywy jest zawsze pułapką. Czytelnicy, którzy pragną spotkać szlachetnych dzikusów w jej powieściach rozczarują się tak samo jak detektywi tropiący jej antypolskie nastawienie. Niektórzy z jej odżibwejskich bohaterów bywają szlachetni, tak jak niektóre z jej postaci z domieszką polskiej krwi zachowują się czasem jak ograniczeni fanatycy/fanatyczki. Ostatecznie jednak trudno zapomnieć, że największą miłością Agnes/Damiena pozostaje Fryderyk Chopin, a sztuczny patos „szlachetnego dzikusa” służy jako niewyczerpane źródło żartów w powieściach Erdrich. To, co wydaje się mieć największe znaczenie, to umiejętność stworzenia kreatywnej więzi z własną tradycją, która zawsze jest, do pewnego stopnia, mieszana. Ojciec Travis musi odrzucić „Boga kiełbasy i pierogów” (czyli bezrefleksyjną intuicyjną wersję katolicyzmu odziedziczoną po rodzicach) i zastanowić się, co dla niego stanowi istotę religii, jeżeli chce odnaleźć siebie, tak samo jak Agnes/Damien musiała znaleźć wspólny mianownik dla swoich korzeni niemiecko-amerykańskich, tradycji odżibwejskiej i fascynacji muzyką Chopina. Literatura, definiowana przez rdzennych Amerykanów jako współczesna forma tradycji gawędziarskiej, może pomóc w odzyskaniu historii, pamięci i siebie samego/siebie samej, dokładnie

${ }^{25}$ L. Erdrich, The Last Report..., dz. cyt., s. 145. 
tak jak udało się to Agnes/Damienowi w jej pojedynku z psem przypominającym Szatana, który zamiast duszy zażądał pamięci właśnie:

The Dog: "(...) Yes, but now I have it. I have your memory."

"No, you don't!" Though weakening, Agnes was indignant. "You'll never have my memory. Even I don't have it all, you rotten hound. (...) You took my memory, and I have spent my whole life gathering it back."

Agnes shut down, closed her eyes, imagined herself a bulwark, a wall. "Of course I loved Nanapush," she went on, impatient. "The old man was my teacher, my confidant, my priest's priest, my confessor, my friend. Plus, he was funny and you don't get funny much in this life. God, how we used to laugh! Even his funeral was hilarious - I miss him. There is no one I want to visit except in the Ojibwe heaven, and so at this late age I'm going to convert, stupid dog, and become at long last the pagan that I always was at heart before I was Cecylia, when I was just Agnes, until I was seduced and diverted by the music of Chopin."

"That neurasthenic pierogi snarfer?"

The dog ranted - it had never liked the composer, it turned out it was jealous but Agnes didn't notice anymore. She fought. (...) Called every ancestor, blood and adopted. (...) Cried out for the young, strong spirit of Mashkiigikwe. For Chopin. (...) Went further, back into the folds of brain that hid and held in their recesses such memories as she had of her childhood, girlhood, lost messages. (...) Agnes screamed, bent her fingers into wire hangers around the mange-bald throat, locked her knees, squeezed harder, harder, harder, until the dog yelped, gave up, and disappeared. ${ }^{26}$

[Pies: „(...) Tak, ale teraz mam ją. Mam twoją pamięć”.

„Nie, nie masz!" Chociaż coraz słabsza, Agnes była nieprzejednana. „Nigdy nie będziesz mieć mojej pamięci. Nawet ja jej nie posiadam, ty gnijący ogarze. (...) Zabrałeś mi pamięć i spędziłam całe życie na jej odzyskiwaniu”.

Agnes zamilkła, zamknęła swe oczy i wyobraziła sobie, że jest bastionem i ścianą. „Oczywiście kochałam Nanapusha”, dodała niecierpliwie. „Ten starzec był moim nauczycielem, moim powiernikiem, przełożonym duchownym, moim spowiednikiem i przyjacielem. Poza tym był zabawny, a życie nie dostarcza zbyt wiele zabawy. Boże, jak myśmy się potrafili śmiać! Nawet jego pogrzeb był zabójczo śmieszny - tęsknię za nim. Nie znam nikogo, kogo chciałabym odwiedzić, z wyjątkiem tych z nieba Odżibwejów, i dlatego na starość, głupi psie, zamierzam się nawrócić i stać się poganką, którą zawsze w głębi serca byłam, zanim stałam się Cecilią, gdy byłam zaledwie Agnes, zanim uwiodła mnie muzyka Chopina, porywając moje życie w innym kierunku".

„Tego neurastenicznego pożeracza pierogów?”

26 Tamże, s. 310-311. 
Pies wygłosił tyradę, bo nigdy nie lubił kompozytora - okazało się, że był o niego zazdrosny - ale Agnes już tego nie zauważyła. Podjęła walkę. (...) Przywołała w myślach wszystkich przodków, spokrewnionych z nią i adoptowanych. (...) Wykrzyknęła imię młodego i silnego ducha Mashkiigikwe. Imię Chopina. (...) Zanurzyła się głęboko, penetrując najgłębsze zakamarki mózgu skrywające w swoich przepaściach jej wspomnienia z czasów, gdy była dzieckiem i nastolatką, utracone wiadomości. (...) Agnes wrzasnęła, a jej palce, niczym druciane wieszaki, zacisnęły się wokół wyliniałego od świerzbu gardła, jej kolana zablokowały się, naciskając na psie cielsko coraz mocniej i mocniej aż w końcu pies zaskowyczał, poddał się i zniknął"].

\section{Bibliografia}

„The Art of Fiction” zima 2010, nr 208 (195).

Bak H., Toward a Native American 'Realism': The Amphibious Fiction of Louise Erdrich, [w:] Neo-Realism in Contemporary American Fiction, red. K. Versluys, Amsterdam 1992.

Bordewich M., Killing the White Man's Indian, New York 1996.

Deloria V. Jr., Custer Died For Your Sins. An Indian Manifesto, New York 1969.

Erdrich L., LaRose, New York 2016.

Erdrich L., The Last Report on the Miracle at Little No Horse, New York 2001.

Erdrich L., Love Medicine, New York 1984.

Erdrich L., The Master Butchers Singing Club, London 2004, wyd. polskie: Klub spiewających rzeźników, tłum. K. Bieńkowska, Warszawa 2003.

Erdrich L., The Round House, New York 2012.

Erdrich L., Tracks, New York 1988.

Horwitz T., Podróż dtuga i dziwna. Drugie odkrywanie Nowego Świata, tłum. J. Miklos, Warszawa 2011.

The Inconvenient Indian. A Curious Account of Native "Fergus” People in North America, Minneapolis 2012.

Jacobs C.A., The Novels of Louise Erdrich. Stories of Her People, New York 2001.

King Th., Kloppenburg M.R., Contemporary Trickster Tales: The Pillagers in Louise Erdrich North Dakota Quartet and Their Stories of Survival, Essen 1999.

Krupat A., Ethnocriticism. Ethnography, History, Literature, Berkeley 1992.

Krupat A., The Turn to the Native. Studies in Criticism and Culture, Lincoln 1996.

Moristuen-Rodakowski J., The Turtle Mountain Reservation in North Dakota in Louise Erdrich's Love Medicine [w:] Louise Erdrich's „Love Medicine”. A Casebook, red. H.D. Sweet Wong, Oxford 2000.

Owens L., Other Destinies: Understanding the American Indian Novel, Norman 1992.

Rainwater C., Dreams of Fiery Stars. The Transformations of Native American Fiction, Philadelphia 1999. 
Rainwater C., Reading Between Worlds: Narrativity in the Fiction of Louise Erdrich [w:] Louise Erdrich's „Love Medicine”: A Casebook, ed. H.D. Sweet Wong, New York 2000.

Reel Injun, reż. N. Diamond, 2009 (dokument).

Treuer D., Native American Fiction, A User's Manual, Minneapolis 2006.

Wilson J., The Earth Shall Weep: A History of Native America, New York 1998. 